\title{
“Coral Dominance”: A Dangerous Ecosystem Misnomer?
}

\author{
Peter S. Vroom \\ Ocean Associates, contracted to NOAA Pacific Island Fisheries Science Center Coral Reef Ecosystem Division, \\ 1125 B Ala Moana Boulevard, Honolulu, HI 96814, USA \\ Correspondence should be addressed to Peter S. Vroom, peter.vroom@noaa.gov
}

Received 10 June 2010; Revised 4 October 2010; Accepted 19 October 2010

Academic Editor: Robert J. Toonen

Copyright (C) 2011 Peter S. Vroom. This is an open access article distributed under the Creative Commons Attribution License, which permits unrestricted use, distribution, and reproduction in any medium, provided the original work is properly cited.

\begin{abstract}
Over 100 years ago, before threats such as global climate change and ocean acidification were issues engrossing marine scientists, numerous tropical reef biologists began expressing concern that too much emphasis was being placed on coral dominance in reef systems. These researchers believed that the scientific community was beginning to lose sight of the overall mix of calcifying organisms necessary for the healthy function of reef ecosystems and demonstrated that some reefs were naturally coral dominated with corals being the main organisms responsible for reef accretion, yet other healthy reef ecosystems were found to rely almost entirely on calcified algae and foraminifera for calcium carbonate accumulation. Despite these historical cautionary messages, many agencies today have inherited a coral-centric approach to reef management, likely to the detriment of reef ecosystems worldwide. For example, recent research has shown that crustose coralline algae, a group of plants essential for building and cementing reef systems, are in greater danger of exhibiting decreased calcification rates and increased solubility than corals in warmer and more acidic ocean environments. A shift from coral-centric views to broader ecosystem views is imperative in order to protect endangered reef systems worldwide.
\end{abstract}

\section{Introduction}

Around the globe, tropical to subtropical reef ecosystems are at risk. Environmental threats in the form of pollution, overfishing, alien species, global warming, and ocean acidification have led to the documented decline of coral communities in numerous marine ecosystems [1-9] and allowed macroalgal overgrowth to result in potentially nonreversible phase shifts in many locations $[5,10-14]$. Management efforts will hopefully help to preserve and protect the imperiled ecosystems in which corals live; however, scientific terminology may be thwarting responsible conservation efforts by creating false representations of tropical to subtropical reefs in the minds of the general public and governmental management agencies. Many reef systems contain areas composed primarily of coral, but these areas are interspersed among other types of ecologically necessary, hard-bottomed, carbonate-accreting, reef areas that contain little to no coral. Recognition of the essential role these noncoral-dominated reef areas play to the overall health status and accretion of reef ecosystems will help to ensure that effective reef management measures are accomplished.

\section{What Constitutes a Healthy Reef?}

Reef researchers from past decades described many healthy tropical to subtropical reef systems as containing a higher percentage of noncoral calcifying organisms than scleractinian corals [15-18]. As noted almost a century ago by scientists studying algal communities in tropical reef settings, the term "coral reef" itself fosters a false perception of many tropical to subtropical marine communities $[17,18]$. This misnomer promotes one type of calcifying reef organism over numerous others that are also essential for healthy reef ecosystem function and growth. Researchers from the late 1800 s and early 1900s tried to steer public and management agency views away from a coral-centric perception in order to force researchers to recognize that many reefs naturally exhibit low coral cover, and reef accretion occurs primarily from layers of calcified algal deposits and foraminifera [1519]. More recently, some researchers have attempted to reinforce this historic concept by promoting terms such as "coralgal" or "tropical (or subtropical)" reef systems instead of "coral" reef systems [20-23]. Fortunately, these efforts have been successful among tropical marine scientists, who 
recognize the diversity of calcifying organisms necessary for healthy reef growth. An increasing number of management agencies and conservation programs are also broadening their scope and shifting from coral-centric research $[24,25]$ to ecosystem-based research that encompasses a varied mixture of calcifying organisms. In order for effective reef conservation efforts to progress in a meaningful way, continued recognition of the diversity of noncoral calcifying organisms that occur in healthy reef ecosystems, coupled with the recognition that many tropical marine ecosystems naturally contain vast areas of low coral cover, should be recognized.

Currently, no consensus exists among biologists on the best way to define a healthy tropical to subtropical, hardbottomed, reef system. However, all researchers would likely agree that high biodiversity, high fish biomass, intact apex predator communities, low incidences of disease, and the ability to accrete calcium carbonate faster than erosion occurs are among key factors in defining health [23, 2630]. During the past few decades, high coral cover (coral dominance) was also sometimes intrinsically equated with high reef health [30-33]; however, while high coral cover is a sign of high reef health in some cases, this paradigm does not hold true for many healthy reef ecosystems. As the title of this paper suggests, a danger exists in promoting healthy reefs as being those dominated by coral because other calcifying biological organisms, such as crustose coralline red algae, calcified macroalgae, and foraminifera, that are also critical for reef accretion and maintenance may get overlooked. Understanding the long-term effects of increased ocean acidity and temperature on noncoral calcifying organisms is just as important as understanding the long-term effects on coral for the survival of reef systems overall.

\section{What Is Meant by Coral Dominance?}

Why is there such a widespread belief (especially among nongovernmental organizations, the general public, and, subsequently, grass root conservation efforts) that: (1) high coral cover is necessary for reef accretion, (2) high coral cover indicates a healthy reef ecosystem, and (3) algae (particularly macroalgae) are detrimental to tropical reef environments? Some of these misconceptions may stem from the fact that early marine ecology programs historically were constituted with a diversity of botanists as well as zoologists [19, 34-36], but it is rare for current reef or marine ecology programs to include a diversity of (or even one) marine botanists. For example, despite the diversity of evolutionary groups represented by algae and foraminifera, as well as the concern over ecological impacts of algae to reef systems, only $3 \%$ of publications from the 11th International Coral Reef Symposium in 2008 focused on algae (40\% dealt with coral, 12\% with fish, and 7\% with noncoral invertebrates) [37]. If coral biologists form the largest component of benthic monitoring programs, it is not surprising that an unintentional bias in sampling towards coral-dominated tropical ecosystems has occurred. Coral biologists usually do not visit hardbottomed reef areas that do not contain coral. However, this has likely led to underrepresentation of hard-bottomed communities that naturally contain expansive stretches of algal-dominated environments in past scientific studies.

In order to create an understanding amongst scientists and reef managers, the scientific community must better define what is meant by "coral dominance" and how it relates to healthy reef ecosystems. How much coral exists in a "coraldominated" environment [12]? Is coral dominance: (1) a state where corals cover more than $50 \%$ of the substrate, (2) a state where, out of the numerous organisms that occur in reef settings, corals occupy a greater percent of the substrate than any other type of organism (even though the actual percent cover of coral may be low), or finally (3) a state where corals occupy a greater amount of substrate than only a select group of organisms (e.g., macroalgae)? When hard-bottomed reef tracts are considered as a whole, very few of even the healthiest Pacific island reefs exhibit an average percent cover of corals over $50 \%$ (Figures 1 and 2) $[22,23]$. Therefore, defining a coral-dominated reef system as one that naturally contains vast expanses where corals exceed 50\% cover does not make sense for most Pacific island reef ecosystems. In fact, in the least impacted Pacific ecosystems monitored by the National Oceanic and Atmospheric Administration, Pacific Islands Fisheries Science Center's Coral Reef Ecosystem Division (CRED), the vast majority exhibit average island-wide percent cover of calcified red algae ranging from $1 \%$ to $42 \%$ and scleractinian corals ranging from $2 \%$ to $40 \%$ (Figure 2) [39]. Even when fleshy noncalcified macroalgae are considered, they often occupy a greater amount of substrate than hard corals at a majority of sites in some of the healthiest reef ecosystems in the Pacific (Figure 2) [22, 23, 40], and despite recent negative perceptions of the role of macroalgae in reef systems $[5,10-14]$, comparing ratios of these two functional groups often cannot be used to define the health status of the reef.

\section{Why Should We Care about Algae on Reef Systems?}

Clearly, constructional coral species have been important to the buildup of many reef systems for millennia on a global scale [41-47], and efforts to conserve extant areas of high coral cover are essential. However, the scientific community must create a better conduit to reef managers to promote the fact that not all reef systems are the same. While some healthy reefs are dominated by constructional coral species [41-45], others contain almost no coral (sometimes termed incipient reefs) $[17,19,47,48]$, and others rely on a mix of calcified algae, foraminifera, and coral $[17,20,21]$. As M. A. Howe states in a 1912 Science magazine article:

"From what may be observed to-day in the tropics as to the relative dominance of calcareous marine plants and calcareous marine animals and from what has been determined by the study of cores obtained by boring into coral reefs, it would appear that sometimes the plants predominate and sometimes the animals." 


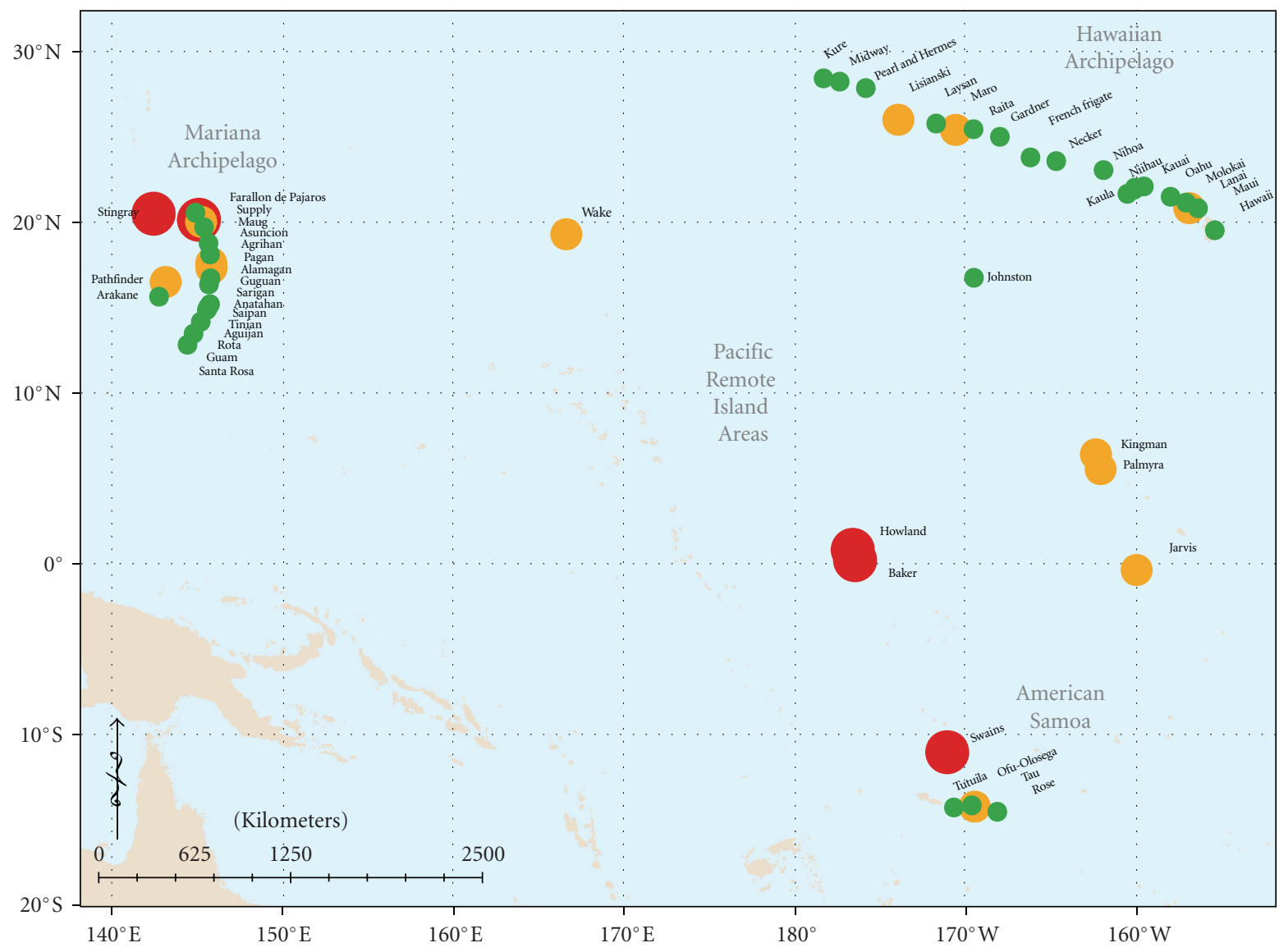

Towed-diver coral cover (\%)

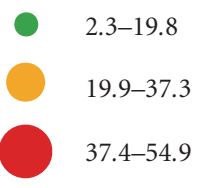

FIgURE 1: Average island-wide percent cover of scleractinian corals on islands under U.S. jurisdiction in the Pacific Ocean. Many of these reefs are considered to be among the least impacted tropical marine ecosystems in existence, yet average coral cover rarely exceeds $30 \%$ and is $<18 \%$ at the majority of islands monitored. Percent cover data were collected via CRED towed-diver surveys [38] from 2000 through 2009 Reef Assessment and Monitoring Program research expeditions. Figure credit: Tomoko Acoba.

Calcareous algae include not only crustose coralline red genera, but also calcified macroalgae such as species of the segmented, green genus Halimeda, which are the main producers of carbonate sediments in many reef systems [16, 49-52]. A 1904 coring study that examined reefs to a depth of over $330 \mathrm{~m}$ at Funafuti Atoll (Tuvalu) revealed that the organisms responsible for reef accretion in order of importance were: (1) crustose coralline red algae, (2) Halimeda, (3) foraminifera, and lastly, coral [16]. Other classic and recent studies provide similar results, revealing portions of many fossil and existent reef systems from around the globe that are composed primarily of algal or foraminiferal deposits (e.g., Fiji [53], the Gilbert Islands [54], Indonesia [19], Bermuda [55, 56], Atol das Rocas (Brazil) [57], Ukraine [58], Hawaii [59], Australia [52], Spain [51], and Sardinia [60]. Despite these numerous studies, many (although not all) management agencies continue to remain fixated on coral as being the dominant organism responsible for reef growth [61] in all areas.

The adoption of randomly stratified sampling designs by current reef monitoring programs has greatly increased our understanding of the actual diversity and abundance of benthic communities that are typical of normal, healthy tropical to subtropical Pacific marine ecosystems, and reinforce historic reef concepts discussed by pioneer researchers more than a century ago $[15-19,53,56]$. Since 2000 , CRED has been conducting interdisciplinary monitoring of $\sim 50$ islands scattered throughout the Pacific Ocean (Figure 1). Although every island monitored contains areas of dense coral cover, these coral rich areas are often limited in size, and the majority of hard-bottomed reef community consists of substrate dominated by algal functional groups [22, 23, 40, $62]$. Thus, island-wide cover of live corals rarely exceeds more than $30 \%$, and the majority of US-held islands in the tropical 


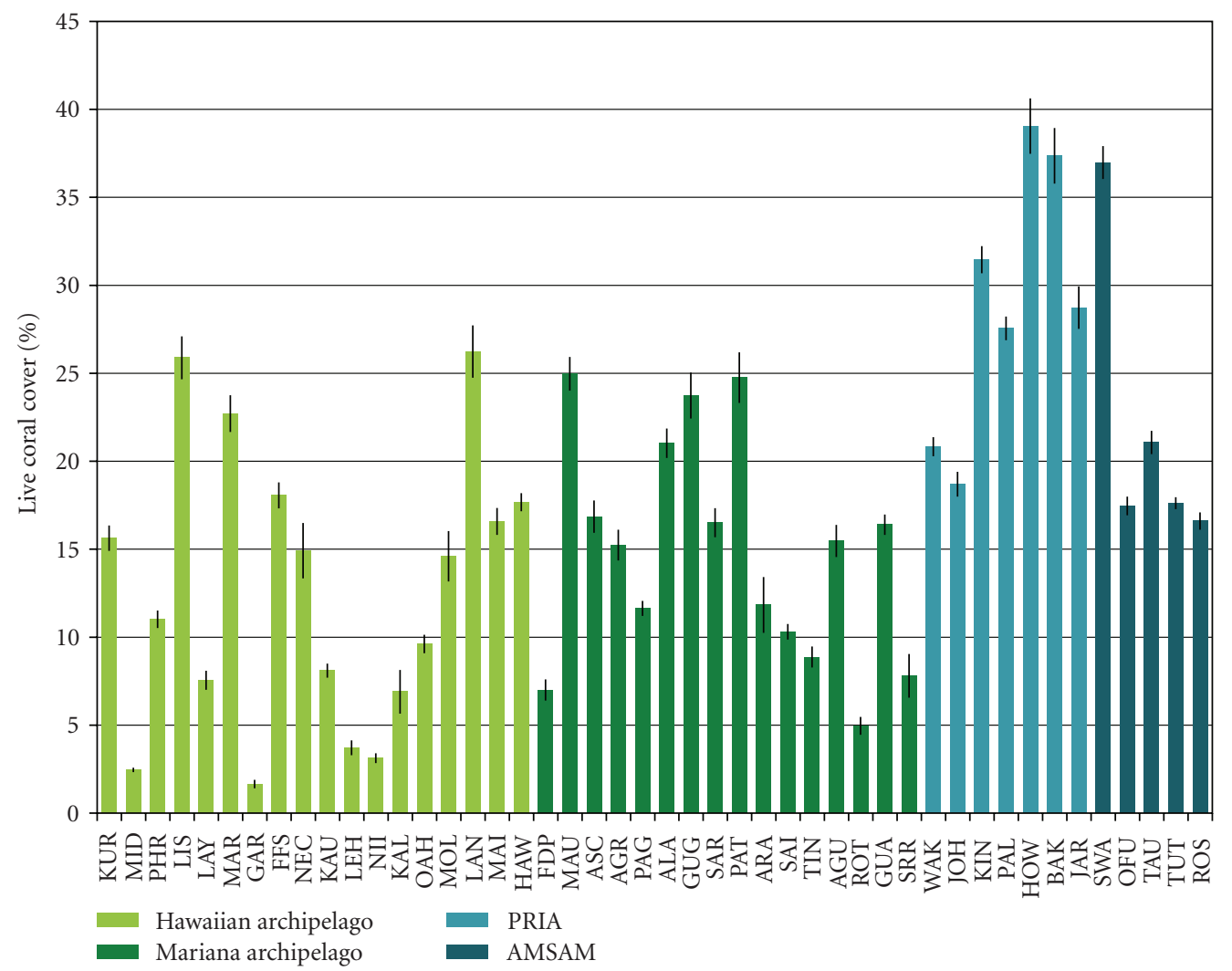

(a)

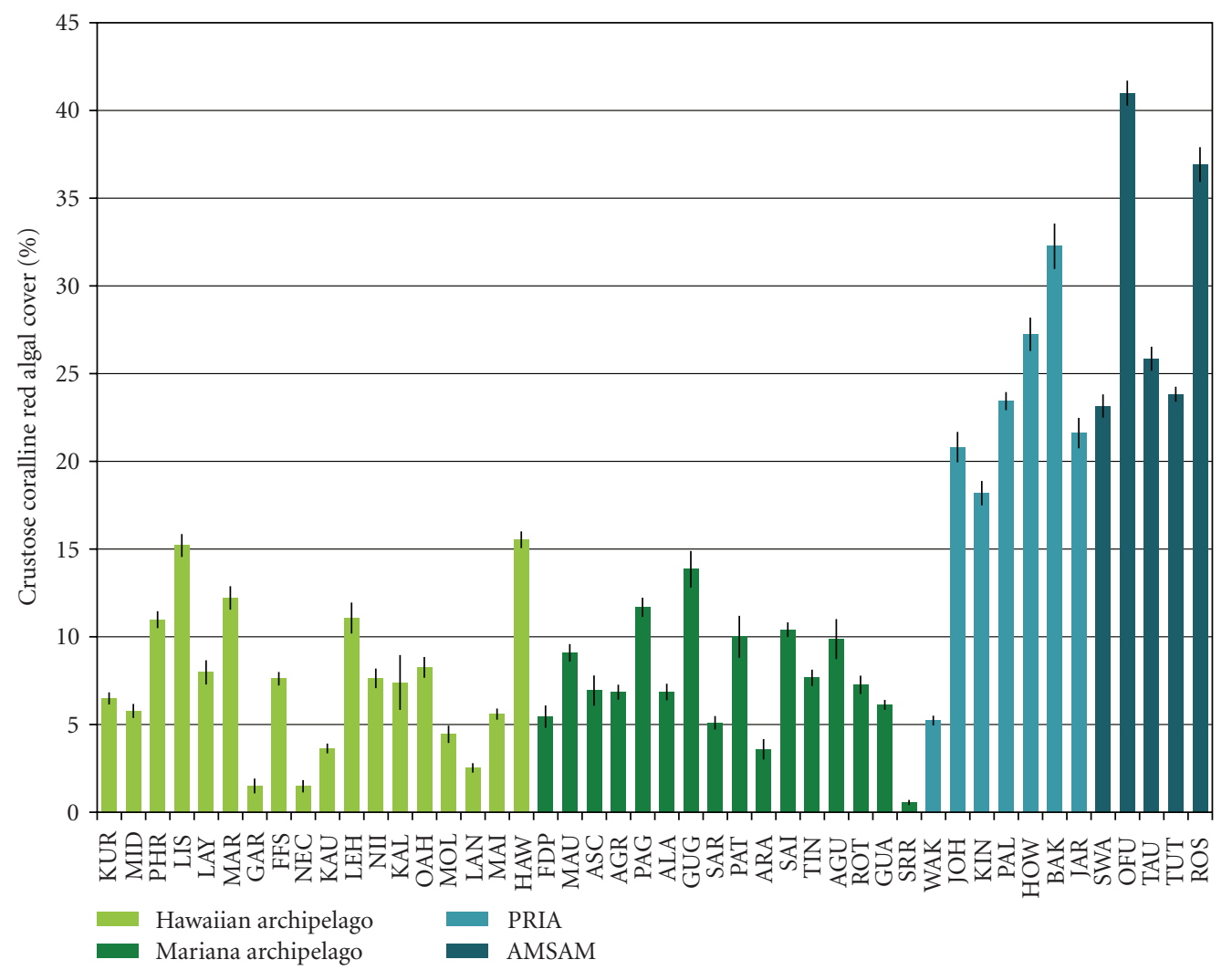

(b)

Figure 2: Continued. 


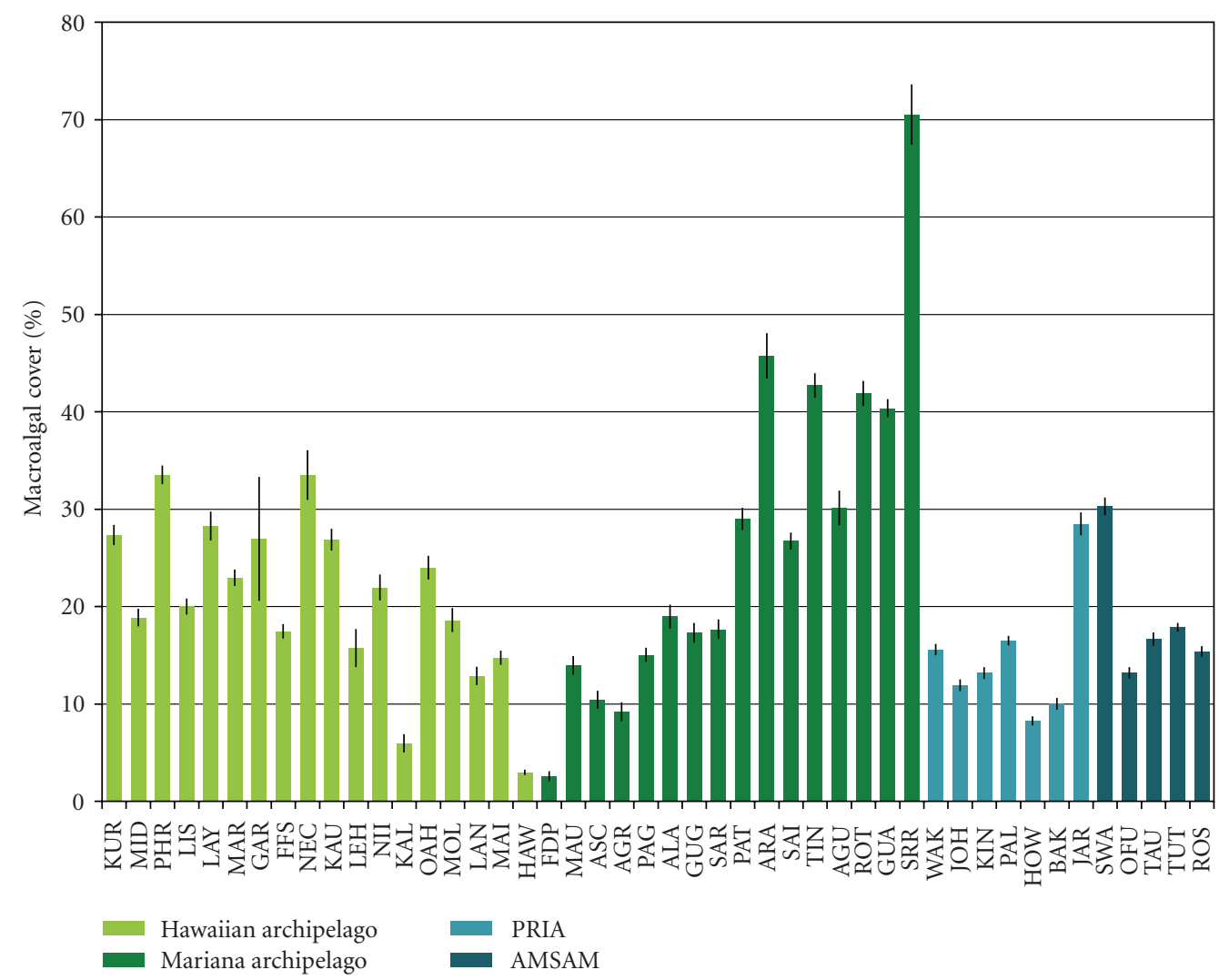

(c)

Figure 2: Average percent cover data of (a) live coral, (b) crustose coralline red algae, and (c) macroalgae (both calcified and noncalcified (fleshy) algae which often are attached on top of living CCA communities) collected via CRED towed-diver surveys [38] from 2000 through 2009 Reef Assessment and Monitoring Program research expeditions. Islands within each archipelagic system are arranged in geographic order from north to south (left to right), and archipelagic systems are also presented in geographic order from north to south (although latitudinal overlap between archipelagic systems is not represented; see Figure 1). Standard error bars are provided. Figure credit: Amanda Toperoff and Tomoko Acoba.

to subtropical Pacific contain island-wide percent cover of live coral $<18 \%$ (Figures 1 and 2). CCA pavements and macroalgal communities (which often epiphytically grow on top of living CCA crusts, but rarely exceed $10-15 \mathrm{~cm}$ in height in tropical to subtropical reef systems) combined typically occupy a much greater percentage of substrate than live coral (Figures 2 and 3 ).

Considering that healthy reefs rely on significant populations of CCA (as well as other types of algal communities), I am concerned about reef management and funding agencies that are focused on monitoring health of just coral and fish communities. Reefs are integrated ecosystems, and our attempts to conserve coral communities will not be successful if efforts are not also made to conserve many of the noncharismatic organisms in reef systems. Recent research has documented that crustose coralline algal (CCA) communities are at greater risk to changes in sea surface temperature and ocean acidification than coral communities [63-67], yet rarely do we see the conservation of algal communities being promoted to the same degree as conservation of coral communities. Unlike coral skeletons that are composed primarily of aragonite and calcite, CCA skeletons contain magnesian calcite [63]. Magnesian calcite has a higher solubility than aragonite or calcite, and CCA growth is expected to be completely inhibited under less acidic conditions than would completely inhibit coral growth [63-65]. In other words, many calcified algae essential for reef accretion and reef cementation will be severely impacted by ocean acidification and warming before corals [66, 67]. Additionally, since CCA are one of the main settlement platforms for coral larvae, this will likely have a profound effect on coral survival [63].

\section{Conclusions}

The author's concerns over the misconceptions of "coral dominance" in reef systems are that: (1) reef management agencies are losing sight of ecosystem-based research and may potentially overlook many essential calcifying organisms (e.g., crustose coralline red algae, foraminifera, and $\mathrm{Hal}$ imeda) that should be closely researched in order to better understand the effects of ocean acidification and warming, (2) unrealistic perceptions of what constitutes a healthy reef (e.g., that high coral cover is always necessary) may 


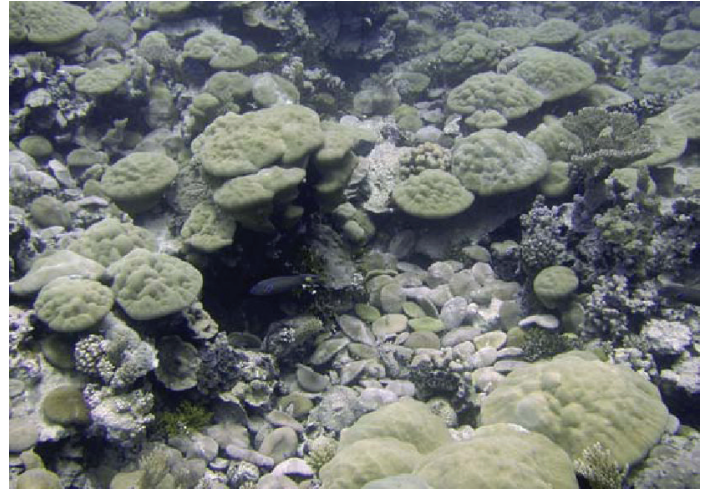

(a)

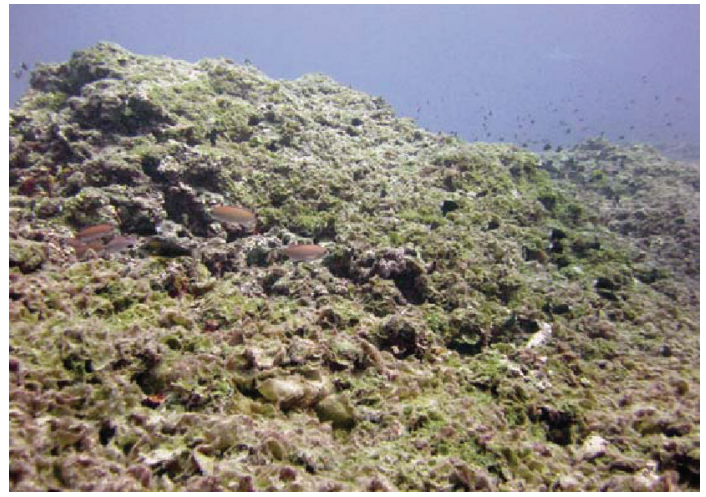

(b)

Figure 3: Examples of two reef systems monitored by NOAA's Coral Reef Ecosystem Division. (a) Kingman Reef, US Line Islands. Kingman Reef contains areas exhibiting extremely dense and diverse scleractinian coral communities. Although this tropical marine ecosystem may approximate the idealized image of reef health held by the general public and some management agencies, this type of tropical reef community is one end of a spectrum that ranges from coral-dominated to algal-dominated environments in the healthy reef ecosystems monitored by NOAA on tropical to subtropical Pacific Islands. (b) Pearl and Hermes Atoll, Northwestern Hawaiian Islands. Containing $\sim 5 \%$ cover of scleractinian corals, this healthy reef system contains dense pavements of crustose coralline red algae overgrown by the foliose green macroalga, Microdictyon, which in turn is often covered with turf algal epiphytes. Such reef environments with relatively low coral cover are more representative of many types of reef communities monitored by NOAA on tropical to subtropical Pacific Islands than the coral-dominated environment picture in Figure 2(a). Photo credit: Cristi L. Braun (CRED).

permeate the public and reef management agencies and will be perpetuated indefinitely, and (3) reef management agencies might try to restore ecosystems to nonnatural states where essential elements of reef systems become lost because too much emphasis was placed on only a single type of organism (e.g., coral).

As reef scientists, we recognize the increasing number of threats that are causing reefs to decline worldwide. Coral rich areas are valuable reef resources, and need extra management protection, but not to the exclusion of noncoral dominated areas that also contain essential reef building organisms.
In complex ecosystems, all organisms are interconnected. We know from current research that CCA communities will likely be adversely impacted by global climate change sooner than coral communities. Since many coral species rely on CCA as larval settlement platforms, efforts equal to understanding coral responses to global climate change should also be put towards understanding changes in algal communities. Fortunately, responsible reef management programs are increasingly recognizing the diverse suite of noncoral calcifying organisms present in reef settings that also deserve protection and study [61], but some programs do continue to overlook important calcifying organisms such as CCA, Halimeda, and foraminifera that are necessary for reef maintenance and accretion in many areas. As scientists, we should strive towards removing any remaining disconnects with management agencies and promote research and conservation of all calcifying, framework or sediment producing organisms that will be affected by global climate change. There is a common English idiom describing a person who cannot perceive the "big picture" because of concentrating too intently on minute details that states "one cannot see the forest for the trees." This is an apt saying that applies to reef research today. Please do not lose sight of the reefs because of the coral. Reefs are integrated ecosystems, and all components should to be studied and conserved for these endangered habitats to survive.

\section{Acknowledgments}

The author wish to thank Cristi Richards and Rodney Withall at NOAA's Coral Reef Ecosystem Division (CRED) for providing critical review, Tomoka Acoba (CRED) for map generation, and the crews of the NOAA Ships Townsend Cromwell, Oscar Elton Sette, and Hi'ialakai for field support. Funding to CRED for scientific expeditions was provided through NOAA's Coral Reef Conservation Program.

\section{References}

[1] T. P. Hughes, A. H. Baird, D. R. Bellwood et al., "Climate change, human impacts, and the resilience of coral reefs," Science, vol. 301, no. 5635, pp. 929-933, 2003.

[2] T. P. Hughes, M. J. Rodrigues, D. R. Bellwood et al., "Phase shifts, herbivory, and the resilience of coral reefs to climate change," Current Biology, vol. 17, no. 4, pp. 360-365, 2007.

[3] J. M. Pandolfi, R. H. Bradbury, E. Sala et al., "Global trajectories of the long-term decline of coral reef ecosystems," Science, vol. 301, no. 5635, pp. 955-958, 2003.

[4] J. M. Pandolfi, J. B. C. Jackson, N. Baron et al., "Are U.S. coral reefs on the slippery slope to slime?" Science, vol. 307, no. 5716, pp. 1725-1726, 2005.

[5] D. R. Bellwood, T. P. Hughes, C. Folke, and M. Nyström, "Confronting the coral reef crisis," Nature, vol. 429, no. 6994, pp. 827-833, 2004.

[6] J. F. Bruno and E. R. Selig, "Regional decline of coral cover in the Indo-Pacific: timing, extent, and subregional comparisons," PLoS One, vol. 2, no. 8, article e711, 2007.

[7] M. H. Ledlie, N. A. J. Graham, J. C. Bythell et al., "Phase shifts and the role of herbivory in the resilience of coral reefs," Coral Reefs, vol. 26, no. 3, pp. 641-653, 2007. 
[8] M. Adjeroud, F. Michonneau, P. J. Edmunds et al., "Recurrent disturbances, recovery trajectories, and resilience of coral assemblages on a South Central Pacific reef," Coral Reefs, vol. 28, no. 3, pp. 775-780, 2009.

[9] E. Vivekanandan, M. H. Ali, B. Jasper, and M. Rajagopalan, "Vulnerability of corals to warming of the Indian seas: a projection for the 21st century," Current Science, vol. 97, no. 11, pp. 1654-1658, 2009.

[10] T. Done, E. Turak, M. Wakeford, L. DeVantier, A. McDonald, and D. Fisk, "Decadal changes in turbid-water coral communities at pandora reef: loss of resilience or too soon to tell?" Coral Reefs, vol. 26, no. 4, pp. 789-805, 2007.

[11] J. B. C. Jackson, M. X. Kirby, W. H. Berger et al., "Historical overfishing and the recent collapse of coastal ecosystems," Science, vol. 293, no. 5530, pp. 629-637, 2001.

[12] J. W. McManus and J. F. Polsenberg, "Coral-algal phase shifts on coral reefs: ecological and environmental aspects," Progress in Oceanography, vol. 60, no. 2-4, pp. 263-279, 2004.

[13] T. P. Hughes, "Catastrophes, phase shifts, and large-scale degradation of a Caribbean coral reef," Science, vol. 265, no. 5178, pp. 1547-1551, 1994.

[14] M. J. Shulman and D. R. Robertson, "Changes in the coral reefs of San Bias, Caribbean Panama: 1983 to 1990," Coral Reefs, vol. 15, no. 4, pp. 231-236, 1996.

[15] M. J. Shulman and D. R. Robertson, "Three cruises of the Blake," Bulletin of the Museum of Comparative Zoology at Harvard College, vol. 14, no. 4, pp. 1-314, 1888.

[16] A. E. Finckh, "Biology of the reef-forming organisms at Funafuti Atoll, Section VI," in The Atoll of Funafuti, Report of the Coral Reef Committee, pp. 125-150, Royal Society, London, UK, 1904.

[17] M. A. Howe, "The building of "coral" reefs," Science, vol. 35, no. 909, pp. 837-842, 1912.

[18] W. A. Setchell, "Coral reefs as zonational plant formations," Science, vol. 68, no. 1754, pp. 119-121, 1928.

[19] A. Weber-van Bosse and M. Foslie, "The corallinaceae of the siboga-expedition," in Siboga-Expeditie, E. J. Brill, Ed., vol. 61, pp. 1-110, Leiden, The Netherlands, 1904.

[20] J. R. Bryan and P. F. Huddlestun, "Correlation and age of the Bridgeboro Limestone, a coralgal limestone from southwestern Georgia," Journal of Paleontology, vol. 65, no. 5, pp. 864-868, 1991.

[21] J. A. Fagerstrom and O. Weidlich, "Biologic response to environmental stress in tropical reefs: lessons from modern Polynesian coralgal atolls and Middle Permian sponge and Shamovella-microbe reefs (Capitan Limestone USA)," Facies, vol. 51, no. 1-4, pp. 517-531, 2005.

[22] P. S. Vroom, C. A. Musburger, S. W. Cooper, J. E. Maragos, K. N. Page-Albins, and M. A.V. Timmers, "Marine biological community baselines in unimpacted tropical ecosystems: spatial and temporal analysis of reefs at Howland and Baker Islands," Biodiversity and Conservation, vol. 19, no. 3, pp. 797$812,2010$.

[23] P. S. Vroom and C. L. Braun, "What is the benthic composition of a healthy subtropical reef? Baseline species-level percent cover, with an emphasis on reef algae, in the Northwestern Hawaiian Islands," Plos One, vol. 5, no. 3, Article ID e9733, 2010.

[24] C. F. Barbosa, M. D. F. Prazeres, B. P. Ferreira, and J. C. S. Seoane, "Foraminiferal assemblage and reef check census in coral reef health monitoring of East Brazilian margin," Marine Micropaleontology, vol. 73, no. 1-2, pp. 62-69, 2009.
[25] J. D. Schueth and T. D. Frank, "Reef foraminifera as bioindicators of coral reef health: low isles reef, Northern Great Barrier Reef, Australia," Journal of Foraminiferal Research, vol. 38, no. 1, pp. 11-22, 2008.

[26] D. Fautin, P. Dalton, L. S. Incze et al., "An overview of marine biodiversity in United States waters," PLoS One, vol. 5, no. 8, Article ID e11914, 2010.

[27] S. C. Jameson, M. V. Erdmann, J. R. Karr, and K. W. Potts, "Charting a course toward diagnostic monitoring: a continuing review of coral reef attributes and a research strategy for creating coral reef indexes of biotic integrity," Bulletin of Marine Science, vol. 69, no. 2, pp. 701-744, 2001.

[28] P. Bradley, W. S. Fisher, H. Bell et al., "Development and implementation of coral reef biocriteria in U.S. jurisdictions," Environmental Monitoring and Assessment, vol. 150, no. 1-4, pp. 43-51, 2009.

[29] R. S. Appeldoorn, "Transforming reef fisheries management: application of an ecosystem-based approach in the USA Caribbean," Environmental Conservation, vol. 35, no. 3, pp. 232-241, 2008.

[30] P. J. Mumby, "Phase shifts and the stability of macroalgal communities on Caribbean coral reefs," Coral Reefs, vol. 28, no. 3, pp. 761-773, 2009.

[31] I. A. Leiper, U. E. Siebeck, N. J. Marshall, and S. R. Phinn, "Coral health monitoring: linking coral colour and remote sensing techniques," Canadian Journal of Remote Sensing, vol. 35, no. 3, pp. 276-286, 2009.

[32] H. Huang, J. Lian, X. Huang, L. Huang, R. Zou, and D. Wang, "Coral cover as a proxy of disturbance: a case study of the biodiversity of the hermatypic corals in Yongxing Island, Xisha Islands in the South China Sea," Chinese Science Bulletin, vol. 51, no. 2, pp. 129-135, 2006.

[33] A. J. Uychiaoco, H. O. Arceo, S. J. Green, M. T. De La Cruz, P. A. Gaite, and P. M. Aliño, "Monitoring and evaluation of reef protected areas by local fishers in the Philippines: tightening the adaptive management cycle," Biodiversity and Conservation, vol. 14, no. 11, pp. 2775-2794, 2005.

[34] H. T. Odum and E. P. Odum, "Trophic structure and productivity of a windward coral reef community on Eniwetok Atoll," Ecological Monographs, vol. 25, no. 3, pp. 291-320, 1955.

[35] A. Gepp and E. S. Gepp, "The codiaceae of the siboga expedition," in Monographs of the Siboga Expedition, E. J. Brill, Ed., vol. 62, p. 150, Leiden, The Netherlands, 1911.

[36] E. S. Barton, "The genus halimeda," in Monographs of the Siboga Expedition, E. J. Brill, Ed., vol. 60, p. 32, Leiden, The Netherlands, 1901.

[37] C. Miller and V. Kosmynin, "The effects of hurricanedeposited mud on coral communities in Florida," in Proceedings of the 11th International Coral Reef Symposium, vol. 1-2, pp. 1-1425, Fort Lauderdale, Fla, USA, July 2008.

[38] J. C. Kenyon, R. E. Brainard, R. K. Hoeke, F. A. Parrish, and C. B. Wilkinson, "Towed-diver surveys, a method for mesoscale spatial assessment of Benthic Reef habitat: a case study at Midway Atoll in the Hawaiian Archipelago," Coastal Management, vol. 34, no. 3, pp. 339-349, 2006.

[39] P. S. Vroom, K. N. Page, J. C. Kenyon, and R. E. Brainard, "Algae-dominated reefs," American Scientist, vol. 94, no. 5, pp. 430-437, 2006.

[40] P. S. Vroom and M. A. V. Timmers, "Spatial and temporal comparison of algal biodiversity and benthic cover at gardner pinnacles, Northwestern Hawaiian Islands," Journal of Phycology, vol. 45, no. 2, pp. 337-347, 2009. 
[41] R. C. Baron-Szabo, A. Schafhauser, S. Götz, and W. Stinnesbeck, "Scleractinian corals from the cardenas formation (Maastrichtian), San Luis Potosí, Mexico," Journal of Paleontology, vol. 80, no. 6, pp. 1033-1046, 2006.

[42] J. M. Pandolfi, "A new, extinct Pleistocene reef coral from the Montastraea "annularis" species complex," Journal of Paleontology, vol. 31, no. 3, pp. 472-482, 2007.

[43] S. Schroeder, "Stratigraphy and systematics of rugose corals from the Givetian and sub-Frasnian regions of the Rheinisches Schiefergebirg (Sauerland/Bergisches Land)," Zitteliana Reihe $B$, vol. 25, no. 3, pp. 39-116, 2005.

[44] R. B. Aronson, I. G. Macintyre, A. M. Moesinger et al., "History of reef coral assemblages on the rhomboid shoals of belize," Smithsonian Contributions to the Marine Sciences, vol. 38, pp. 313-321, 2009.

[45] C. M. Wapnick, W. F. Precht, and R. B. Aronson, "Millennialscale dynamics of staghorn coral in Discovery Bay, Jamaica," Ecology Letters, vol. 7, no. 4, pp. 354-361, 2004.

[46] W. H. Adey, "Coral reef morphogenesis: a multidimensional model," Science, vol. 202, no. 4370, pp. 831-837, 1978.

[47] P. Houk and J. Starmer, "Constraints on the diversity and distribution of coral-reef assemblages in the volcanic Northern Mariana Islands," Coral Reefs, vol. 29, no. 1, pp. 59-70, 2010.

[48] R. Villaça, A. C. Fonseca, V. K. Jensen, and B. Knoppers, "Species composition and distribution of macroalgae on Atol das Rocas, Brazil, SW Atlantic," Botanica Marina, vol. 53, no. 2, pp. 113-122, 2010.

[49] O. N. Dragastan and H.-G. Herbig, "Halimeda (green siphonous algae) from the paleogene of (Morocco)taxonomy, phylogeny and paleoenvironment," Micropaleontology, vol. 53, no. 1-2, pp. 1-72, 2007.

[50] J. N. Harney and C. H. Fletcher III, "A budget of carbonate framework and sediment production, Kailua Bay, Oahu, Hawaii," Journal of Sedimentary Research, vol. 73, no. 6, pp. 856-868, 2003.

[51] J. M. Martín, J. C. Braga, and R. Riding, "Late Miocene Halimeda alga-microbial segment reefs in the marginal Mediterranean Sorbas Basin, Spain," Sedimentology, vol. 44, no. 3, pp. 441-456, 1997.

[52] S. A. Rees, B. N. Opdyke, P. A. Wilson, and T. J. Henstock, "Significance of Halimeda bioherms to the global carbonate budget based on a geological sediment budget for the Northern Great Barrier Reef, Australia," Coral Reefs, vol. 26, no. 1, pp. 177-188, 2007.

[53] J. S. Gardiner, "The coral reefs of Funafuti, Rotuma, and Fiji, together with some notes on the structure and formation of coral reefs in general," Proceedings of the Cambridge Philosophical Society, vol. 9, pp. 417-503, 1898.

[54] J. S. Gardiner, The Fauna and Geography of the Maldive and Laccadive archipelagoes: Being the Account of the Work Carried on and of the Collections Made by an Expedition During the years 1899 and 1900, Cambridge University Press, 1901.

[55] A. Agassiz, "A visit to the Bermudas in March, 1894," Bulletin of the Museum of Comparative Zoology at Harvard College, vol. 26, pp. 205-281, 1895.

[56] H. B. Bigelow, "Contributions from the bermuda biological station for research-no. 5: the shoal water deposits of the Bermuda banks," Proceedings of the American Academy of Arts and Sciences, vol. 40, pp. 557-597, 1905.

[57] D. F. M. Gherardi and D. W. J. Bosence, "Composition and community structure of the coralline algal reefs from Atol das Rocas, South Atlantic, Brazil," Coral Reefs, vol. 19, no. 3, pp. 205-219, 2001.
[58] A. Radwański, M. Górka, and A. Wysocka, "Middle miocene coralgal facies at Maksymivka near Ternopil (Ukraine): a preliminary account," Acta Geologica Polonica, vol. 56, no. 1, pp. 89-103, 2006.

[59] J. M. Webster, D. A. Clague, J. C. Braga et al., "Drowned coralline algal dominated deposits off Lanai, Hawaii; carbonate accretion and vertical tectonics over the last $30 \mathrm{ka}$," Marine Geology, vol. 225, no. 1-4, pp. 223-246, 2006.

[60] M.-F. Benisek, C. Betzler, G. Marcano, and M. Mutti, "Coralline-algal assemblages of a Burdigalian platform slope: implications for carbonate platform reconstruction (northern Sardinia, western Mediterranean Sea)," Facies, vol. 55, no. 3, pp. 375-386, 2009.

[61] J. M. Pandolfi and J. B. C. Jackson, "Algae, corals, and reef health," American Scientist, vol. 95, p. 5, 2007.

[62] P. S. Vroom, K. N. Page, K. A. Peyton, and J. K. Kukea-Shultz, "Spatial heterogeneity of benthic community assemblages with an emphasis on reef algae at French Frigate Shoals, Northwestern Hawai'ian Islands," Coral Reefs, vol. 24, no. 4, pp. 574-581, 2005.

[63] K. R. N. Anthony, D. I. Kline, G. Diaz-Pulido, S. Dove, and O. Hoegh-Guldberg, "Ocean acidification causes bleaching and productivity loss in coral reef builders," Proceedings of the National Academy of Sciences of the United States of America, vol. 105, no. 45, pp. 17442-17446, 2008.

[64] S. Martin and J.-P. Gattuso, "Response of Mediterranean coralline algae to ocean acidification and elevated temperature," Global Change Biology, vol. 15, no. 8, pp. 2089-2100, 2009.

[65] J. E. N. Veron, O. Hoegh-Guldberg, T. M. Lenton et al., "The coral reef crisis: the critical importance of $<350 \mathrm{ppm} \mathrm{CO}_{2}$," Marine Pollution Bulletin, vol. 58, no. 10, pp. 1428-1436, 2009.

[66] I. B. Kuffner, A. J. Andersson, P. L. Jokiel, K. S. Rodgers, and F. T. MacKenzie, "Decreased abundance of crustose coralline algae due to ocean acidification," Nature Geoscience, vol. 1, no. 2, pp. 114-117, 2008.

[67] P. L. Jokiel, K. S. Rodgers, I. B. Kuffner, A. J. Andersson, E. F. Cox, and F. T. Mackenzie, "Ocean acidification and calcifying reef organisms: a mesocosm investigation," Coral Reefs, vol. 27, no. 3, pp. 473-483, 2008. 

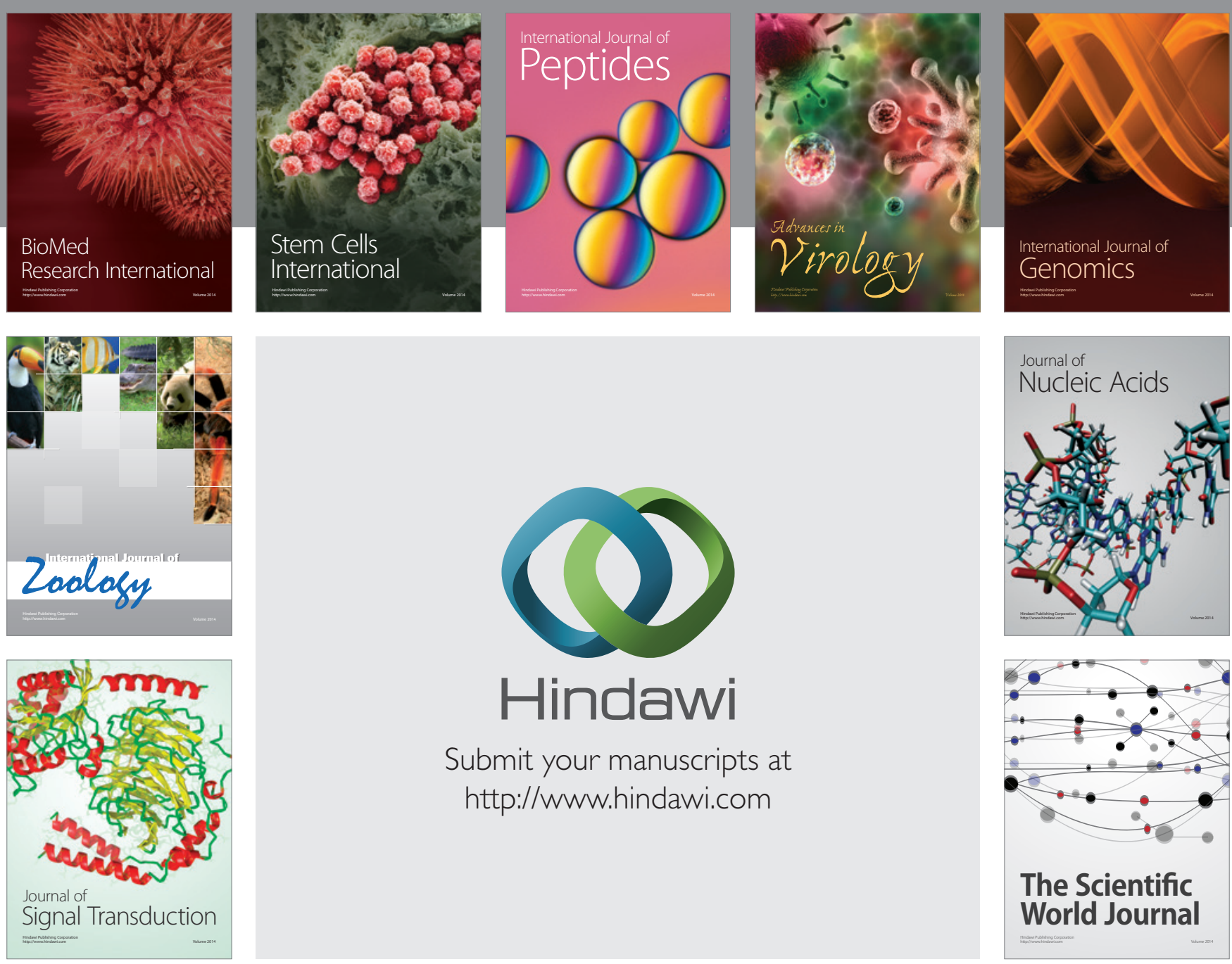

Submit your manuscripts at

http://www.hindawi.com
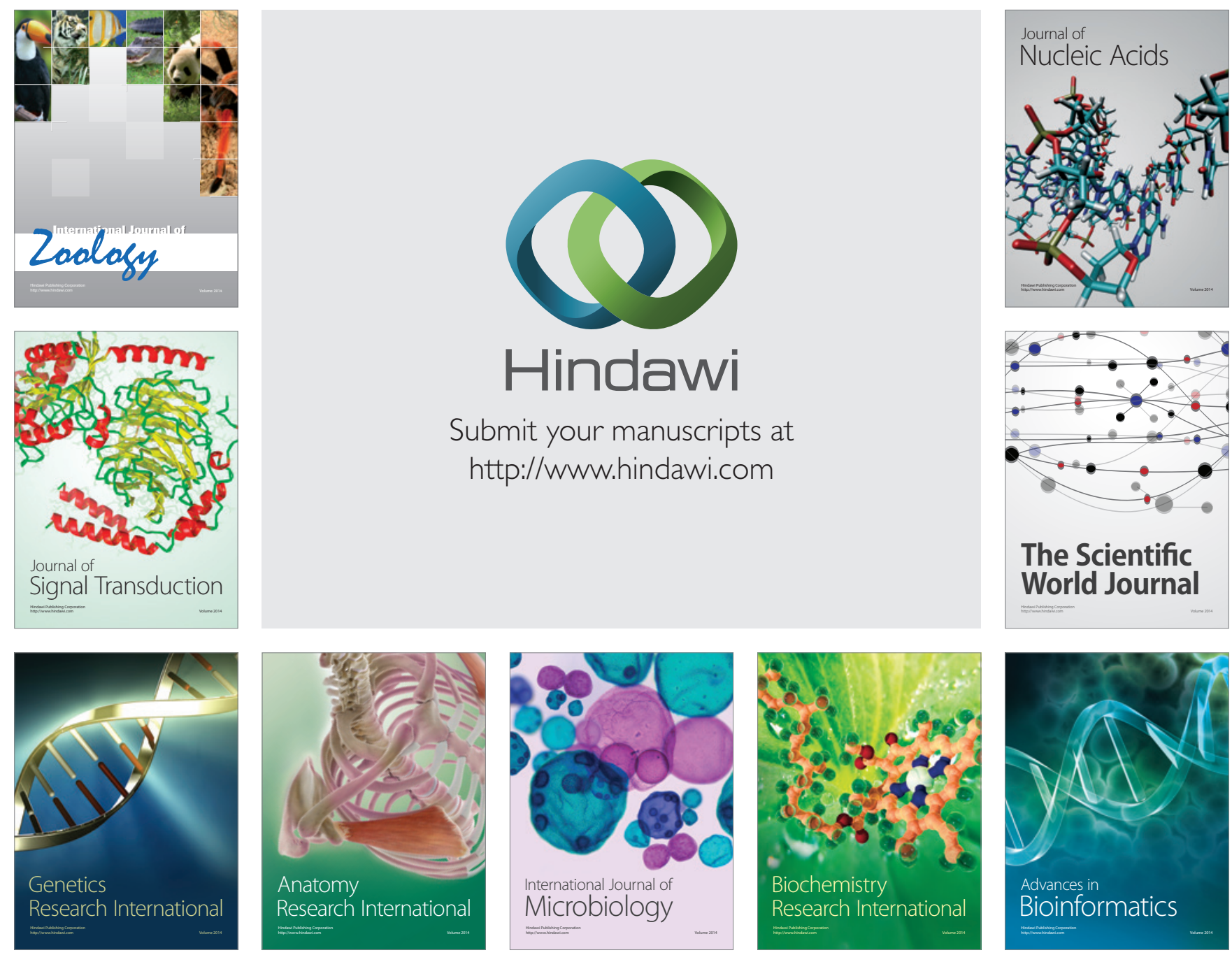

The Scientific World Journal
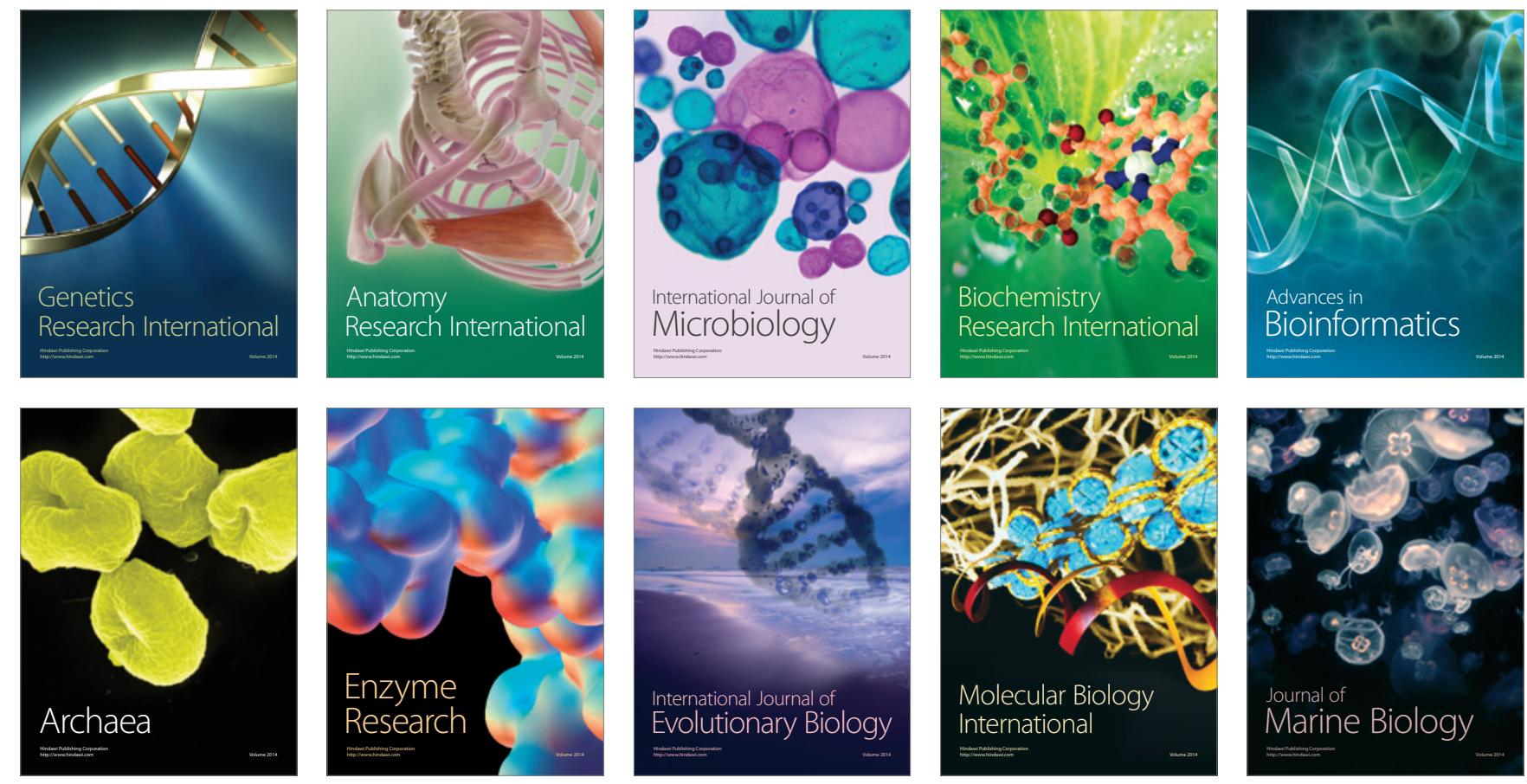